О.М. Кононець, О.В. Ткаченко

Національна медична академія післядипломної освіти імені П.Л. Шупика, Київ

\title{
Деякі клініко-неврологічні характеристики у пацієнтів із нирковою патологією
}

Мета - вивчити клініко-неврологічні характеристики ураження нервової системи (НС) при нирковій патології. Об'єкт і методи дослідження. Представлено результати фрагменту комплексного обстеження 24 пацієнтів із хронічною хворобою нирок (ХХH). Проведено детальне клініко-неврологічне, нейропсихологічне (визначення рівнів конституційної та реактивної тривожностіза шкалою Спілбергера - Ханіна), лабораторне(з визначенням параметрів електролітного балансу, азотного обміну, автоімунних маркерів пошкодження мозкової та ниркової тканин) та інструментальне обстеження (ультразвукове дослідження нирок, магнітно-резонансна томографія головного мозку). Результати. У пацієнтів із ХХН виявлено ознаки ураження структур як центрального, так і периферичного відділів НС, а також вегетативної НС. Висновки. Наявність чисельних патогенетичних механізмів пошкодження центрального, периферичного та автономного відділів НС при ХХН, недостатне вивчення механізмів ураження НС при нирковій патології, а також взаємних впливів НС та нирок за умови патології, враховуючи зростаючу медико-соціальну значущість пацієнтів з нирковою патологією, зокрема ХХН, зумовлюють необхідність подальшого детального комплексного дослідження клінічних, неврологічних, нейропсихологічних та параклінічних характеристик у цієї категорії пацієнтів.

Ключові слова: хронічна хвороба нирок, клініко-неврологічні характеристики.

\section{Вступ}

Хронічна хвороба нирок (XXН) є досить поширеною медикосоціальною проблемою, яку, згідно з сучасними даними, діагностують у близько 10\% світової популяції. XXН - основна причина формування термінальної стадії хвороби нирок і одна з причин зростання кардіоваскулярної смертності (внаслідок порушення мінерального та електролітного обміну, формування ендотеліальної дисфункції, оксидативного стресу тощо). Поряд із зазначеним XXH призводить до швидкопрогресуючого погіршення якості життя пацієнтів.

Загальновідомо, що соматичні захворювання можуть супроводжуватися різними неврологічними та психологічними розладами (Sengupta P., Biswas S., 2016). При XXН неврологічні ускладнення стосуються всіх відділів нервової системи (НC). Ураження центральної НС проявляється у вигляді цереброваскулярної патології (інсульт, транзиторна ішемічна атака), уремічної енцефалопатії, синдрому задньої реверсивної енцефалопатії (Posterior reversible encephalopathy syndrome - PRES), синдрому осмотичної демієлінізації, вторинних запальних церебральних захворювань, синус-тромбозу, епісиндрому (Lakshman S.G. et al., 2016; Sengupta P., Biswas S., 2016; Faille L.D. et al., 2017). Ураження периферичного відділу НС при XXН може проявлятися полінейропатією, мононейропатією, синдромом карпального каналу. Полінейропатію виявляють у 60-98\% пацієнтів із XXН. Частіше це моторно-вегетативна форма, що переважно виражена в нижніх кінцівках. Уремічна полінейропатія характеризується м'язовою слабкістю, рефлекторними та сенсорними розладами (зміна поверхневих та глибоких рефлексів, пекучий біль, дизестезія), вегетативними розладами (ортостатична гіпотензія, судомоторні порушення, еректильна дисфункція, гастроінтестинальні розлади) (Lai S. et al., 2016; Faille L.D. et al., 2017).

Серед пацієнтів із XXH, що перебувають на гемо- чи перитонеальному діалізі, досить поширеними неврологічними ускладненнями є: синдром неадекватного діалізу (проявляється широким спектром вогнищевих та загальномозкових симптомів, у тому числі PRES, основним патогенетичним механізмом якої є вазогенний набряк мозкової тканини), цефалгічний синдром, когнітивні та цереброваскулярні порушення, епісиндром (Lai S. et al., 2016; Sengupta P., Biswas S., 2016).

Складні взаємозумовлюючі зв'язки між інтегруючою НС та внутрішніми органами і системами, зокрема нирками, в нормі та у разі патології ще недостатньо вивчені. Варте уваги дослідження, проведене National Health Institute Recearch Database of Taiwan в період 2000-2012 рр., в якому встановлено, що наявність в анамнезі черепно-мозкової травми середнього і тяжкого ступеня $€$ неза- лежним фактором як розвитку $\mathrm{XXH}$, так і підвищення рівня смертності. Розглядали чисельні можливі патогенетичні механізми, які при черепно-мозковій травмі могли би впливати на формування XXH, зокрема ранні (післятравматична крововтрата, застосування нефротоксичних антибіотиків) та віддалені (порушення низхідних впливів надсегментарних відділів вегетативної НC) фактори впливу на функціонування нирок (Krishnan A.V., Kiernan M.C., 2009).

Таким чином, недостатнє вивчення механізмів ураження НC при нирковій патології, а також взаємних впливів НС і нирок за умови патології, враховуючи зростаючу медико-соціальну значущість пацієнтів із нирковою патологією, зокрема XXН, зумовили проведення детального комплексного дослідження клінічних, неврологічних, нейропсихологічних, параклінічних характеристик у цієї категорії пацієнтів, фрагмент якого представлений нижче.

Мета - уточнення клініко-неврологічних характеристик ураження $\mathrm{HC}$ при нирковій патології.

\section{Об'єкт і методи дослідження}

Представлено результати фрагменту комплексного обстеження 24 пацієнтів із XXH (середній вік - 52 2 2,3 року), яке включало детальне клініко-неврологічне, нейропсихологічне (визначення рівнів конституційної та реактивної тривожності за допомогою шкали Спілбергера - Ханіна), лабораторне (з визначенням параметрів електролітного балансу, азотного обміну, автоімунних маркерів пошкодження мозкової та ниркової тканин) та інструментальне обстеження (ультразвукове дослідження нирок, магнітно-резонансна томографія головного мозку).

\section{Результати та їх обговорення}

У процесі детального клініко-неврологічного обстеження пацієнтів із XXН загалом у всіх виявлені ознаки ураження структур НС. Причому відзначали прояви уражень як центрального, так і периферичного відділів НС, а також вегетативної НC.

Пацієнтів із XXН висловлювали такі скарги: 21 (87,5\%) - на загальну слабкість, 16 (66,7\%) - періодично виникаючий головний біль, 7 (29,2\%) - невмотивовану тривогу, 5 (20,8\%) - порушення сну, 3 (12,5\%) - запаморочення системного і несистемного характеру.

При детальному обстеженні неврологічного статусу у всіх пацієнтів виявлено ураження центрального відділу НС: у 18 (75,0\%)ознаки пірамідної недостатності (патологічні стопні рефлекси), у $7(29,2 \%)$ - феномен орального автоматизму, у 7 (29,2\%) - вестибуло-мозочковий синдром, у 11 (45,8\%) - екстрапірамідні розлади. У 3 (12,5\%) пацієнтів виявлено легкі когнітивні порушення. 
У 19 (79,2\%) хворих виявлено полінейропатію, яка не викликала суб'єктивних відчуттів (навіть при детальному прицільному опитуванні) - у 13 (54,2\%), виявлялась об'єктивно порушенням поверхневої чутливості у вигляді гіперестезії - у 3 (12,5\%), гіпестезії - у 10 (41,7\%), порушенням м'зово-суглобового чуття в міжфалангових суглобах стоп - у 5 (20,8\%), зниженням вібраційного чуття - у $7(29,2 \%)$ пацієнтів та відповідними рефлекторними розладами. Усі симптоми були більш вираженими в нижніх кінцівках. У 6 (25,0\%) пацієнтів полінейропатія проявлялася, окрім об'єктивних змін у неврологічному статусі, ще й суб'єктивними відчуттями, на які активно скаржилися пацієнти, а саме: відчуттям «печіння» в ділянці стоп, онімінням та парестезією кистей та стоп. Рухового дефіциту ні в кого з досліджуваних не виявлено. У $2(8,3 \%)$ пацієнтів відзначено гіпергідроз стоп.

При визначенні рівнів конституційної та реактивної тривожності (за шкалою Спілбергера - Ханіна) у $15(62,5 \%)$ пацієнтів виявлено підвищений рівень реактивної, у 6 (25,0\%) - конституційної тривожності.

У 8 (33,3\%) учасників дослідження виявлено ознаки порушення вегетативного забезпечення, зокрема у $3(12,5 \%)$ - ортостатичну гіпотензію, у 4 (16,7\%) - еректильну дисфункцію, у $5(20,8 \%)$ - порушення судомоторики, що проявлялося гіпергідрозом тулуба та верхніх кінцівок переважно у нічний час.

Таким чином, в ході детального клініко-неврологічного обстеження 24 пацієнтів із XXН у 19 (79,2\%) виявлені ознаки полінейропатії, у 21 (87,5\%) - дисметаболічної (уремічної) енцефалопатії, у $8(33,3 \%)$ - вегетативної дисфункції. Виявлені неврологічні зміни не суперечать даним, описаним у світовій літературі, і можуть бути пов'язані з різними патогенетичними механізмами. Зокрема гормональні порушення, накопичення метаболітів, дисбаланс між активуючими та інгібуючими церебральними нейротрансмітерами, а також дисметаболічні розлади є провідними у формуванні уремічної енцефалопатії (на початкових стадіях розвитку уремічної енцефалопатії підвищується рівень гліцину в цереброспінальній рідині, знижуються рівні глутаміну та $ү$-аміномасляної кислоти. При прогресуванні уремії відбувається накопичення гуанідин-сукцинатної кислоти, що призводить до активації NMDA-рецепторів і пригнічення GABA-рецепторів, що, в свою чергу, може провокувати розвиток міоклонусів та епілептичних нападів). Підвищений рівень гуанідину призводить до пригнічення транскетолази, тіамінзалежного ферменту пентозофосфатного циклу, який є важливою ланкою у процесі синтезу мієліну. Інгібування транскетолази при уремії призводить до порушення мієлінізації у структурах як центрального, так і периферичного відділів HC (Sengupta P., Biswas S., 2016; Faille L.D. et al., 2017).

Порушення функціонування ферментів основного дихального ланцюга при нирковій недостатності призводить до підвищення рівнів аденозинмонофосфату, аденозинтрифосфату (АТФ) та лактату, що, в свою чергу, асоціюється зі зростанням потреби в оксигенації, з одного боку, та підвищеним енергоспоживанням мозкової тканини - 3 іншого. Результатом оксидативного стресу $є$ наростання дисфункції мітохондріальних мембран, їх пошкодження та порушення окисно-відновних процесів у нейронах (Lai S. et al., 2016).

Основним фактором, що призводить до формування аксонопатії при уремії, є мітохондріальна дисфункція та уповільнення аксонального транспорту (як наслідок порушення у ферментативному ланцюгу циклу Кребса), а також пригнічення АТФази натрійкалієвих каналів. У порушенні функціонування периферичних нервів також вагому роль відіграє так звана мембранна дисфункція периневрію, внаслідок чого токсини безперешкодно проникають в ендоневральний простір та спричинюють пряме пошкодження нерва (Lakshman S.G. et al., 2016).

\section{Висновки}

Наявність великої кількості патогенетичних механізмів пошкодження центрального, периферичного та автономного відділів HC при XXH, недостатнє вивчення механізмів ураження НC при нирковій патології, а також взаємних впливів НС та нирок за умови патології, враховуючи зростаючу медико-соціальну значущість пацієнтів із нирковою патологією, зокрема XXН, зумовлюють необхідність подальшого детального комплексного дослідження клінічних, неврологічних, нейропсихологічних та параклінічних характеристик у цієї категорії пацієнтів.

\section{Список використаної літератури}

Faille L.D., Fieuws S., Van Paesschen W. (2017) Clinical predictors and differential diagnosis of posterior reversible encephalopathy syndrome. Acta Neurol. Belg., 117(2): 469-475.

Krishnan A.V., Kiernan M.C. (2009) Neurological complications of chronic kidney disease. Nat. Rev. Neurol., 5(10): 542-551.

Lai S., Mecarelli O., Pulitano P. et al. (2016) Neurological, psychological, and cognitive disorders in patients with chronic kidney disease on conservative and replacement therapy. Medicine (Baltimore), 95(48): e5191.

Lakshman S.G., Ravikumar P., Kar G. et al. (2016) A Comparative Study of Neurological Complications in Chronic Kidney Disease with Special Reference to its Stages and Haemodialysis Status. J. Clin. Diagn. Res., 10(12): OC01-0C04.

Sengupta P., Biswas S. (2016) Dialysis disequilibrium leading to posterior reversible encephalopathy syndrome in chronic renal failure. CEN Case Rep., 5(2): 154-157.

\section{Некоторые клинико-неврологические характеристики у пациентов с почечной патологией}

\section{О.Н. Кононец, Е.В. Ткаченко}

Резюме. Цель - изучить клинико-неврологические характеристики поражения нервной системы (НС) при почечной патологии. Объектиметоды исследования. Представлены результаты фрагмента комплексного обследования 24 пациентов с хронической болезнью почек (ХБП). Проведено детальное клинико-неврологическое, нейропсихологическое (определение уровней конституционной и реактивной тревожности по шкале Спилбергера - Ханина), лабораторное (с определениемпараметров электролитного баланса, азотистого обмена, аутоиммунных маркеров повреждения мозговой ипочечной ткани) и инструментальное обследование (ультразвуковоеисследованиепочек, магнитно-резонансная томография головного мозга). Результаты. У пациентов с ХБП выявлены признаки поражения структур как центрального, так и периферического отделов НС, а также вегетативной НС. Выводы. Наличие многочисленныхпатогенетическихмеханизмов поврежденияцентрального, периферического и автономного отделов НС при ХБП, а также взаимных воздействий НС и почек в условиях патологии, учитывая возрастающую медико-социальную значимость пациентов с почечной патологией, в частности ХБП, обусловливаютнеобходимостьдальнейшего детального комплексного исследования клинических, неврологических, нейропсихологических и параклинических характеристик уэтой категории пациентов.

Ключевые слова: хроническая болезнь почек, клинико-неврологические характеристики.

\section{Some clinical and neurological aspects in patients with renal pathology}

\section{O.M. Kononets, O.V. Tkachenko}

Summary. Objective - to examine clinical and neurological characteristics of the affection of nervous system(NS) in patients with renal pathology. Material and methods. The results of a fragment of a complex examination of 24 patients with chronic kidney disease (CKD) are presented. A detailed clinical and neurological, neuropsychological (determination of levels of constitutional and reactive anxiety by the Spielberger - Khanin scale), laboratory( with detection of the parameters of the electrolyte balance, nitrogen metabolism, autoimmune markers of the cerebral and renal tissue affection) and instrumental examination (renal ultrasonography, magnetic resonance imaging of the brain) was conducted. Results. In patients with CKD the signs of destruction of the central and peripheral NS structures as well as autonomic NS destruction were detected. Conclusions. The large number of pathogenic mechanisms affecting the central, peripheral and autonomic NS under the CKD, mutual impacts of the NS and kidneys in pathologic conditions, taking into account the growing medical and social significance of patients with renal pathology, in particular $C K D$, necessitate the further detailed complex reserch of clinical, neurological, neuropsychologicaland paraclinical characteristics in this categoryof patients.

Key words: chronical kidney disease, clinical and neurological characteristics.

\section{Адреса для листування:}

Ткаченко Олена Василівна

02000, Київ, вул. Підвисоцького, 4 А

Національна медична академія післядипломної

освіти імені П.Л. Шупика,

кафедра неврології № 2

E-mail: neurology-education@ukr.net 